Csaba Felhő, Eszter Rakonczai, Miskolc, Hungary

\title{
FEM INVESTIGATION OF CUTTING FORCE COMPONENTS IN HIGH-FEED FACE MILLING
}

\begin{abstract}
Face milling is widely used cutting method for creating planar surfaces. The efficiency of the machining process can be increased by removing the same undeformed chip cross section with higher feed rates and less allowance. The article shows the effects of this changing $a_{p} / f_{z}$ ratio on the different cutting force components acting both on the workpiece and on the tool. The force values were determined by FEM simulation, and then the results were validated by data obtained by cutting experiments.
\end{abstract}

Keywords: Finite Element Analysis; High feed milling; Cutting force components.

\section{INTRODUCTION}

In today's rapidly changing market environment, and in the strict economic situation, the large-scale development of the cutting industry is not only about designing and developing new processes, machines, but is also about upgrading current processes to increase their productivity and reliability. The different cutting modes play an important role in this. The most important goal of economical production is to achieve the minimum production time per workpiece and the minimum cost of production while maintaining the required surface accuracy. The purpose of finish machining is to produce the specified criteria: shape and size accuracy and surface quality specified by the designer. One important cutting process of today's modern automation driven production industry is face milling, where flat surfaces are machined with increasing accuracy and productivity requirements. One possible method to achieve high productivity and to decrease of the production costs is to decrease the needed allowance for the machining and to utilize high feed rate values. Thus, the material removal can be done faster and the with less material to be removed (thus decreasing the waste as well). Furthermore, some previous researches have suggested [1], that the cutting force components may decrease as well when high feed rates are used among reduced depth of cut values, when the ratio of the depth of cut $\left(a_{p}\right)$ and feed per tooth $\left(f_{z}\right)$ is less than one $\left(a_{p} / f_{z}<1\right)$. This is a relatively new approach of high-feed face milling, and the details are described in [2].

Many researchers have dealt with the modelling of cutting forces in the different cutting processes, and more specifically in the various milling processes. Kim and Ehmann [3] has introduced a procedure for the simulation of the static and dynamic cutting forces in face milling. 
The static model is primarily based on the initial position errors of the inserts and the eccentricity of the spindle. From the relative displacements of the system, the dynamic cutting forces were derived and simulated based on the double modulation principle. The simulated forces were subsequently compared to measured forces as well. Li et al. [4] have presented a theoretical model for forces in milling based on a predictive machining theory and the mechanics of milling. Milling experiments were conducted ti verify the simulation system. Palanisamy et al. [5] have introduced a dynamic cutting force model for end milling to predict the tangential cutting force and the thrust force. Their model was validated with experimental cutting force values during the machining of AISI 1020 steel. Gyliené and Eidukynas [6] have developed a method for the full (without geometry and kinematics simplifications) face milling simulation. The method is based on Smooth Particles Hydrodynamics $(\mathrm{SPH})$, which is the effective numerical technique to solve problems of high deformation. The Finite Element Method (FEM) technology, which is utilized here is a widely used method to simulate the different cutting process characteristics. However, it should be always noted, that the real process is very complex, and therefore most simulation software can only predict the process parameters (e.g. forces, temperatures, stresses, etc.) with less or more errors. It is always recommended to support the obtained values with real experimental data, so this is the case in the actual research as well. FEM was used in [7] to simulate the stresses and forces for a newly developed milling tool design which have special shanks for clamping the cutting inserts into the tool body [8].

In this article, we examine the effect of the changing of the $\mathrm{a}_{\mathrm{p}} / \mathrm{f}_{\mathrm{z}}$ ratio on the material removal characteristics in face milling; the main investigated process parameters were the machining force components acting on the workpiece (Fx, Fy, Fz) and those which are acting on the tool (Fc, Ff, Fp). These force components are shown in Fig. 1.

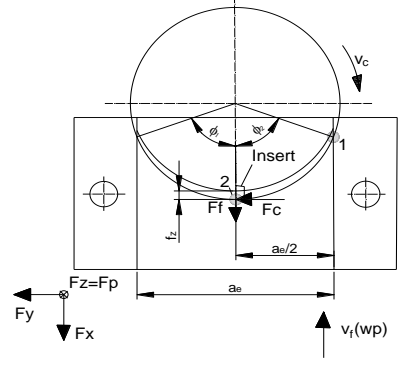

Figure 1 - Cutting force components in face milling 


\section{METHOD AND EQUIPMENT}

The investigation can be divided into two main parts: finite element modelling (FEM) simulations and laboratory experiments. The FEM simulations were performed in the ThirdWave AdvantEdge FEM software, which is specifically designed for the modelling of cutting processes. The laboratory tests were done in the Perfect Jet MCV-M8 vertical milling machine in the shop floor of the Institute of Manufacturing Science, University of Miskolc. The whole machining and force measurement system consist of the following components (Fig 2):

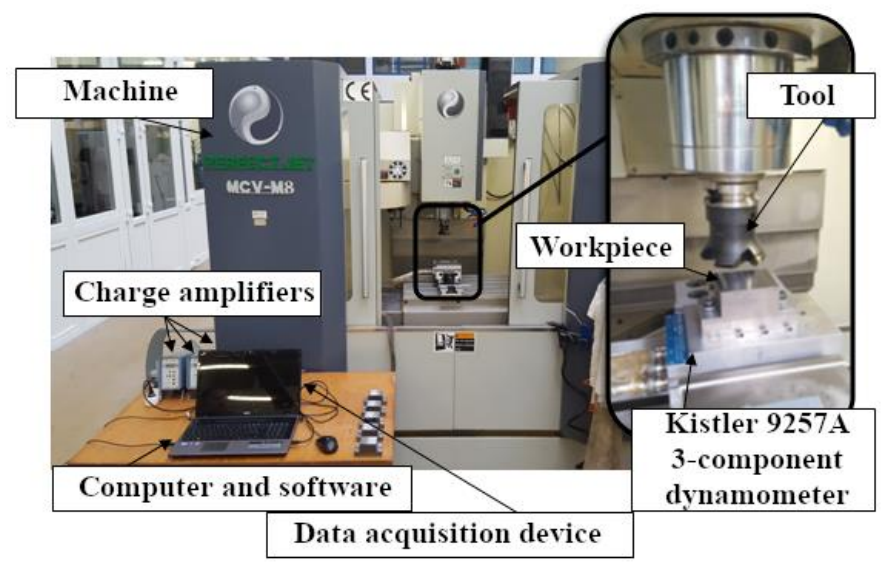

Figure 2 - The machining and force measurement system for experimental tests

Machining system:

- Perfect Jet MCV-M8 vertical milling machine with Sinumerik 828D controller;

- Cutting tool: Coromill R200-068Q27-12L milling head, RCKT1204M0-PM4230 cutting insert, only one insert was used during the cutting (this process is so-called as fly-cutting);

- Workpiece: the material of the specimen is C45 unalloyed carbon steel. The bounding dimensions of the workpiece are $97 \times 50 \times 50 \mathrm{~mm}$, and it has two holes in order to be able to fix it onto the dynamometer.

Force measurement system:

- a Kistler 9257A three-component dynamometer;

- 3 pcs Kistler 5011A charge amplifiers;

- a National Instruments CompactDAQ-9171 four channel data acquisition device; 
- a portable notebook computer with the measurement program, which is written in LabView.

The applied cutting data can be divided into two groups: constant parameters and variable parameters. The constant parameters are shown in Table 1.

Table 1 - The applied constant parameters

\begin{tabular}{|l|c|}
\hline Cutting speed: $\mathrm{v}_{\mathrm{c}}[\mathrm{m} / \mathrm{min}]$ & 150 \\
\hline Spindle speed: $\mathrm{n}[\mathrm{rpm}]$ & 554 \\
\hline Cut width: $\mathrm{ae}_{\mathrm{e}}[\mathrm{mm}]$ & 59 \\
\hline
\end{tabular}

The variable parameters were mainly the depth of cut (DOC) and the feed per tooth (FPT) values. Their values were carefully selected by taking two boundary conditions into account:

- their values should be in the range which is recommended by the tool manufacturer (which is $0.1 \div 0.4$ for FPT, and the $\mathrm{a}_{\text {pmax }}$ is $1.76 \mathrm{~mm}$ );

- the undeformed chip cross section $\mathrm{A}_{\mathrm{c}}$ should be constant: $\mathrm{A}_{\mathrm{c}}=0.8 \mathrm{~mm}^{2}$ for all cases.

Table 2 shows the applied ratios of the DOC and FPT, and the changing of the corresponding feed rate values which were programmed in the machine.

Table 2 - The applied $\mathrm{a}_{\mathrm{p}} / \mathrm{f}_{\mathrm{z}}$ values and their ratios

\begin{tabular}{|l|c|c|c|c|c|}
\hline Sample/Run no. & $\mathbf{1 .}$ & $\mathbf{2 .}$ & $\mathbf{3 .}$ & $\mathbf{4 .}$ & $\mathbf{5 .}$ \\
\hline FPT, $\mathbf{f}_{\mathbf{z}}[\mathbf{m m} / \mathbf{t o o t h}]$ & 0.1 & 0.18 & 0.26 & 0.32 & 0.4 \\
\hline DOC, $\mathbf{a}_{\mathbf{p}}[\mathbf{m m}]$ & 0.8 & 0.44 & 0.31 & 0.25 & 0.2 \\
\hline $\mathbf{a}_{\mathbf{p}} / \mathbf{f}_{\mathbf{z}}$ ratio & 8 & 2.47 & 1.18 & 0.78 & 0.5 \\
\hline Feed rate vf $[\mathbf{m m} / \mathbf{m i n}]$ & 55.4 & 99.72 & 144.04 & 177.28 & 221.6 \\
\hline
\end{tabular}

The same geometrical and technological parameters were used for the simulation part as for the cutting experiments. Of course, the perfect analogy cannot be guaranteed, as there are many uncertainty factors in the system. A good example for this is the exact edge geometry and the edge radius of the insert. In most FEM simulations, usually the cutting edge is considered as a perfect geometrical element, e.g. a line. However, in reality, it cannot be like that. The same thing can be mentioned for the edge radius as well: generally it is not communicated by manufacturers, so usually it should be measured somehow. In our case, we have measured it with an Altisurf 520 surface roughness measurement device by using a LK-G32 displacement sensor. This sensor has a $3000 \mu \mathrm{m}$ measuring range which is large enough to follow both 
the flank and rake face of the insert. Moreover, it can tolerate the shape changes as the laser beam traces the faces and the edge of the tool. Fig 3 . shows the measurement setup with the measured profile.
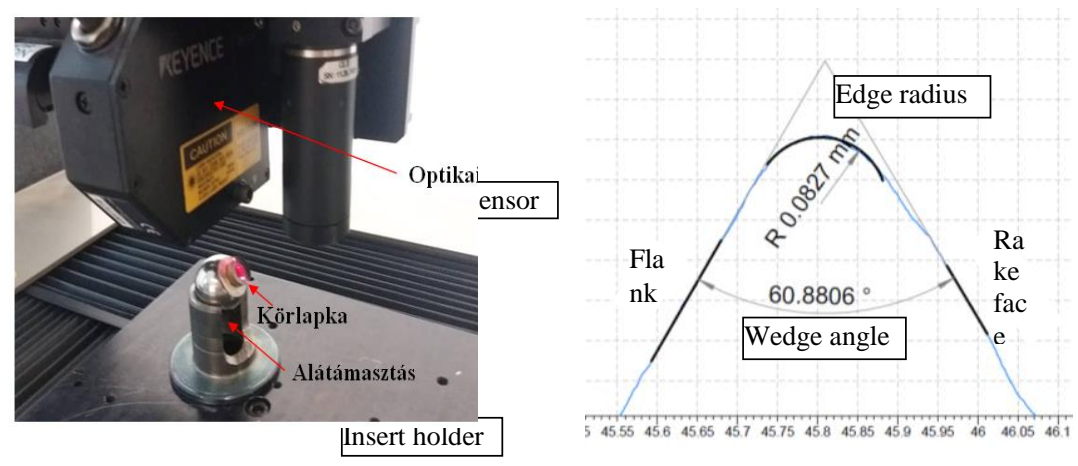

Figure 3 - Cutting edge radius measurement with LK-G32

\section{RESULTS}

At first, results of the FEM simulations are presented. The obtained force components are summarized in Table 3. The table shows the maximum values for the Fx and Fy force components, while for Fz, average values was approximated from the force graph. Fig. 4. shows the obtained force component graphs for Sample 3. The original graph was generated by the system, and the force components can be read out by filtering out the noise from the data by approximating them by a 10-order polynomial. The Fx curve has a special characteristic: it starts to increase, and then it has a maximum point, and then it starts to decrease, and it even enters to the negative domain. This is caused by the rotation of the cutting tool: as the insert leaves the centreline of the milling head, the main cutting force $(\mathrm{Fc})$ is acting counter the ' $x$ ' direction. This is normal for that type of machining. The Fy force component has a clear maximum point, and that point is where the $\mathrm{Fy} \approx \mathrm{Fc}$. The Fz curve is nearly linear, so the average value can be read.

The Fc, Ff and Fp force components were approximated by the following considerations: $\mathrm{Fc} \approx$ Fymax, and this happens when the insert is in the centreline of the milling head. In this moment, the $\mathrm{Ff} \approx \mathrm{Fx}$, as the $\mathrm{Ff}$ in that point is parallel to the $\mathrm{x}$ axis. The Fp is nearly equal to the Fz average value. Of 
course, this is just a rough estimation, and it was assumed, that the $\mathrm{Fc}$ and $\mathrm{Ff}$ values are constant during the cut.

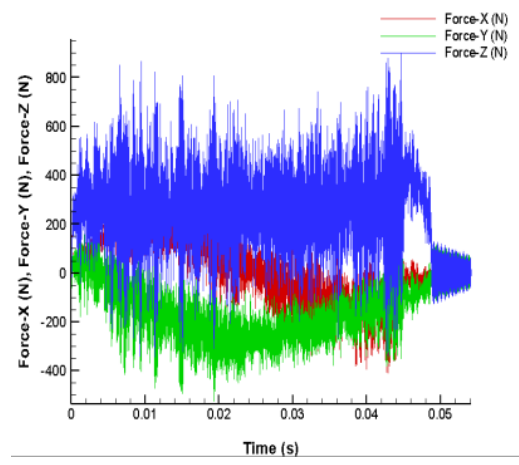

a) original

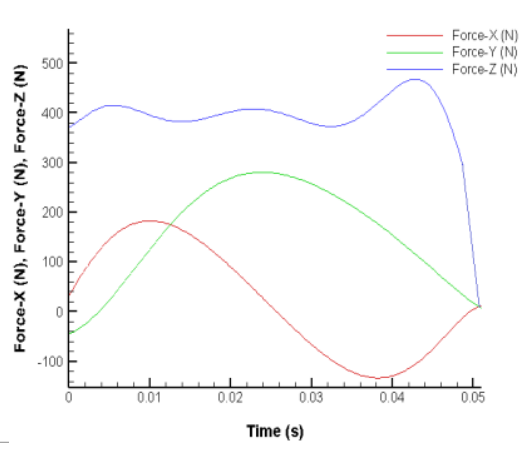

b) filtered

Figure 4 - The original and the filtered simulated force components graph

Table 3 - Simulated force components

\begin{tabular}{|l|c|c|c|c|c|}
\hline \multicolumn{1}{|c|}{ Run no. } & $\mathbf{1}$ & $\mathbf{2}$ & $\mathbf{3}$ & $\mathbf{4}$ & $\mathbf{5}$ \\
\hline $\mathbf{F}_{\mathbf{x m a x}}[\mathbf{N}]$ & 295 & 234.4 & 201 & 139.4 & 149.5 \\
\hline $\mathbf{F}_{\mathbf{y m a x}}[\mathbf{N}]$ & 342.5 & 300.8 & 268.9 & 228.5 & 238.8 \\
\hline $\mathbf{F}_{\mathbf{z}}[\mathbf{N}]$ & 595 & 489 & 424.8 & 413.6 & 487.3 \\
\hline $\mathbf{F}_{\mathbf{c}}[\mathbf{N}]$ & 342.5 & 300.8 & 268.9 & 228.5 & 238.8 \\
\hline $\mathbf{F}_{\mathbf{f}}[\mathbf{N}]$ & 47.5 & 66.4 & 67.9 & 71 & 89.3 \\
\hline $\mathbf{F}_{\mathbf{p}}[\mathbf{N}]$ & 595 & 489 & 424.8 & 413.6 & 487.3 \\
\hline
\end{tabular}

The measured force components are summarized in Table 4. The evaluation principle for the $\mathrm{Fc}, \mathrm{Ff}$ and $\mathrm{Fp}$ force components was the same as it was introduced above. The values are very close to the simulated ones.

Table 4 - Measured force components

\begin{tabular}{|l|c|c|c|c|c|}
\hline Run no. & $\mathbf{1}$ & $\mathbf{2}$ & $\mathbf{3}$ & $\mathbf{4}$ & $\mathbf{5}$ \\
\hline $\mathbf{F}_{\mathbf{x m a x}}[\mathbf{N}]$ & 292.5 & 231.2 & 200.81 & 196.4 & 185.5 \\
\hline $\mathbf{F}_{\mathbf{y m a x}}[\mathbf{N}]$ & 342.1 & 302.4 & 272.07 & 268.5 & 263.6 \\
\hline $\mathbf{F}_{\mathbf{z}}[\mathbf{N}]$ & 575.57 & 472.5 & 429 & 418.25 & 397.17 \\
\hline $\mathbf{F}_{\mathbf{c}}[\mathbf{N}]$ & 342.1 & 302.4 & 272.07 & 268.5 & 263.6 \\
\hline $\mathbf{F}_{\mathbf{f}}[\mathbf{N}]$ & 49.6 & 71.2 & 71.26 & 72.1 & 78.1 \\
\hline $\mathbf{F}_{\mathbf{p}}[\mathbf{N}]$ & 575.57 & 472.5 & 429 & 418.25 & 397.17 \\
\hline
\end{tabular}




\section{DISCUSSION}

Fig. 5 shows the character of changing of the different force components acting on the workpiece (Fx, Fy and Fz). It can be stated from the graph, that all of them are decreasing with the increasing of the feed per tooth and thus decreasing the $a_{p} / f_{z}$ ratio. Therefore, the decreasing of the $a_{p} / f_{z}$ ratio has a positive effect on the stability of the cutting process. However, it should be noted, that the surface roughness is usually deteriorates with the feed increasing, so there should be an optimal point for the actual cutting process [9]. Moreover, the simulated $\mathrm{Fz}$ component has started to increase rapidly at $\mathrm{a}_{\mathrm{p}} / \mathrm{f}_{\mathrm{z}}=$ 0.5 . This shows, that the 'inverse' domain, where this ratio is less than one is not steady, and needs further investigation [10]. There is a slight increase for the simulated Fy and Fx as well at this point, but this changing is not as fast as for Fz.

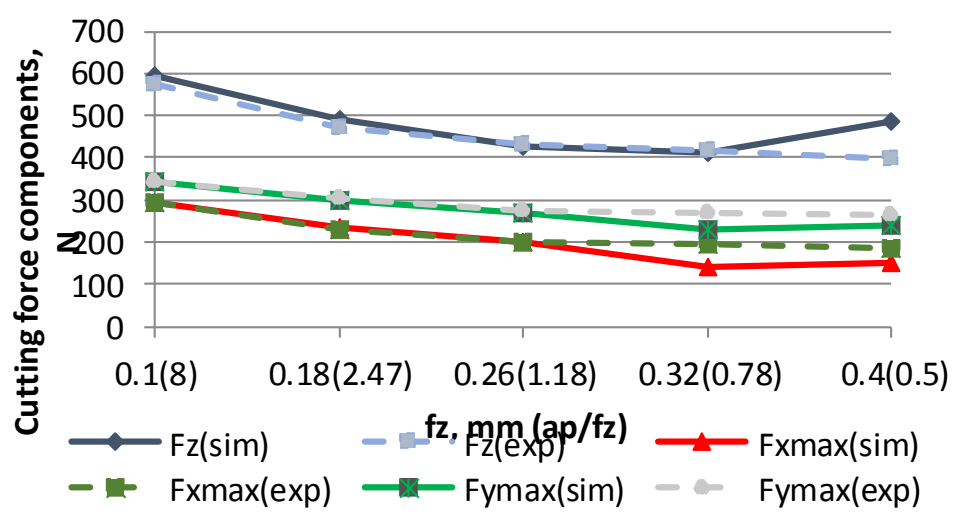

Figure 5 - The character of changing of the Fx, Fy, Fz force components

Fig. 6 shows the simulated and measured values of the Fc, Ff and Fp force components, as well as the theoretical $\mathrm{Fc}$ values $(\mathrm{Fc}(\mathrm{th}))$ which were calculated by the well-known Kienzle-Victor model. It can be stated from the graph, that the $\mathrm{Fc}$ and $\mathrm{Fp}$ components are decreasing for both simulation and measurement until ap/fz $=0.78$, and after that most of them are increasing. The Ff force component has slightly increased all over the investigated range. 


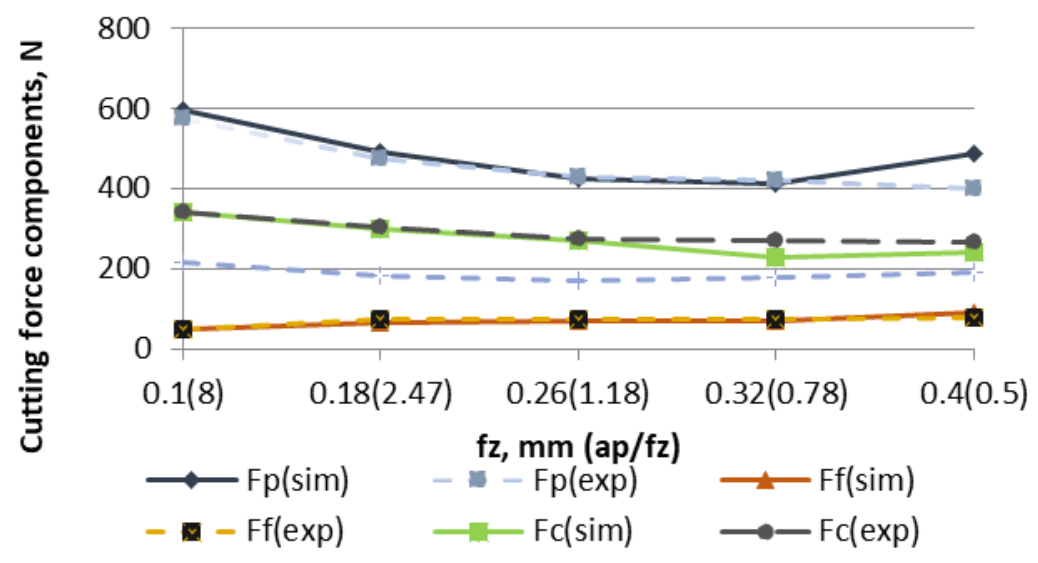

Figure 6 - The character of changing of the Fc, Ff and Fp force components

\section{SUMMARY}

It was presented in the paper, that by removing the same undeformed chip cross-section by decreasing $a_{p} / f_{z}$ ratio (by increasing the $f_{z}$ and decreasing the $a_{p}$ simultaneously) may have positive impact on the force components in face milling. The main cutting force $\mathrm{Fc}$ has shown a clear downward trend together with the Fp component, and the feed force Ff has only slightly increased. However, the Fz and Fp force components have minimum values, those started to increase after $\mathrm{a}_{\mathrm{p}} / \mathrm{f}_{\mathrm{z}}=0.78$, so there may be an optimum point for the process. This domain may need further investigations.

\section{ACKNOWLEDGEMENT}

The authors greatly appreciate the support of the National Research, Development and Innovation Office - NKFIH (No. of Agreement: K 116876). The described study was carried out as part of the EFOP-3.6.1-16-00011 "Younger and Renewing University - Innovative Knowledge City institutional development of the University of Miskolc aiming at intelligent specialization" project implemented in the framework of the program Szechenyi 2020. Both grants are gratefully acknowledged.

References: 1. Kundrák J, Markopoulos AP, Makkai T, Nagy A: Theoretical and Experimental Analysis of the Effect of Chip Size Ratio on Cutting Forces in Face Milling of Steel. International Journal of Mechanical Engineering 2018 3(1): 29-35. 2. Karpuschewski, B., Kundrák, J., Emmer, T., Borysenko, D.: A new strategy in face milling - inverse cutting technology. Solid State Phenomena 2017 261: 331-338 https://doi.org/10.4028/www.scientific.net/SSP.261.331. 3. Kim HS,

Ehmann KF: A cutting force model for face milling operations. International Journal of Machine Tools and Manufacture 1993 33(5): 651-673 https://doi.org/10.1016/0890-6955(93)90099-G. 4. X.P. Li, A.Y.C. Nee, Y.S. Wong, H.Q. Zheng: Theoretical modelling and simulation of milling 
forces. Journal of Materials Processing Technology 1999 89-90:266-272 https://doi.org/10.1016/S0924-0136(99)00076-X. 5. Palanisamy, P., Rajendran, I., Shanmugasundaram, S., Saravanan, $R$. (2006). Prediction of cutting force and temperature rise in the end-milling operation. Proceedings of the Institution of Mechanical Engineers, Part B: Journal of Engineering Manufacture, 220(10), 1577-1587. 6. Gyliene V., Eidukynas V.: The Numerical Analysis of Cutting Forces in High Feed Face Milling Assuming the Milling Tool Geometry. Procedia CIRP 2016 46:436 - 439 https://doi.org/10.1016/i.procir.2016.03.132. 7. Beňo J, Maňková I., Vrábel M., Karpuschewski B., Emmer T., Schmidt K.: Operation Safety and Performance of Milling Cutters with Shank Style Holders of Tool Inserts. Procedia Engineering 2012 48:15-23 https://doi.org/10.1016/j.proeng.2012.09.479. 8. Trung, N. D., Potenzial eines Rundschaft-Fraeswerkzeugsystems fuer Forschung und Produktion. Dr.-Ing. Dissertation, Ottovon-Guericke University Magdeburg, Shaker Verlag Aachen, 2009. 9. Varga, G., Kundrák, J.: Effects of technological parameters on surface characteristics in face milling, Solid State Phenomena 2017 261:285-292. https://doi.org/10.4028/www.scientific.net/SSP.261.285. 10 . Kundrák, J., Markopoulos, A.P., Makkai, T., Deszpoth, I., Nagy, A.: Analysis of the effect of feed on chip size ratio and cutting forces in face milling for various cutting speeds. Manufacturing Technology 2018 18(3):431-438 https://doi.org/10.21062/ujep/117.2018/a/12132489/MT/18/3/431.

\title{
Чаба Фелхо, Эстер Ракончай, Мішкольц, Угорщина
}

\section{FЕМ ДОСЛІДЖЕННЯ КОМПОНЕНТІВ СИЛИ РІЗАННЯ ПРИ ТОРЦЕВОМУ ФРЕЗЕРУВАННІ 3 ВЕЛИКИМИ ПОДАЧАМИ}

\begin{abstract}
Анотація. Ториеве фрезерування $\epsilon$ широко використовуваним методом різання для створення плоских поверхонь. Ефективність процесу обробки може бути збільшена шляхом видалення того ж недеформованого поперечного перерізу стружки з більи високими швидкостями подачі і меншими припусками. У статті показано вплив цього мінливого відношення $a_{p} / f_{z}$ на різні складові сили різання, щео діють як на заготовку, так $i$ на інструмент. Значення сили були визначені за допомогою моделювання FEM (метод кінцевих елементів), а потім результати були підтверджені даними, отриманими в експериментах по різанню. Вивчено характер зміни різних компонентів сили, що діють на заготовку $\left(F_{x}, F_{y}\right.$ i $F_{7}$ ). Можна констатувати, що всі вони зменшуються зі збільшенням подачі на зуб $i$, отже, зі зменшенням відносини $a_{p} / f_{z}$. Таким чином, зменшення відношення $a_{p} / f_{z}$ робить позитивний вплив на стабільність процесу різання. Однак слід зазначити, що шорсткість поверхні зазвичай погіршується зі збільшенням подачі, тому повинна бути оптимальна точка для фактичного прочесу різання. Крім того, змодельована компонента Fz почала швидко зростати при $a_{p} / f_{z}=0,5$. Це показує, щчо «зворотний» домен, де це співвіднотення менше одиниці, не є усталеним $i$ потребує подальшого вивчення. В иій точиі також спостерігається невелике збільшення для модельованих $F_{y}$ i $F_{x}$, але ия зміна не така швидка, як для $F_{z}$. Основна сила різання $F_{c}$ показала чітку тенденцію до зниження разом 3 компонентом $F_{p}$, а сила подачі $F_{f}$ лише незначно збільшилася. Однак складові сили $F_{z} i F_{p}$ мають мінімальні значення, які починають збільшуватися після $a_{p} / f_{z}=0,78$, тому це може бути оптимальна точка для прочесу. Цей домен може зажадати подальших досліджень.
\end{abstract}

Ключові слова: метод кінцевих елементів; фрезерування з великими подачами; компоненти сили різання. 